Pak. j. sci. ind. res. Ser. B: biol. sci. 2019 62B(2) 83-87

\title{
Application of Bromoxynil+MCPA+Metribuzin at Varied Doses for Broad-Spectrum Weed Control in Forage Maize (Zea mays L.)
}

\author{
Muhammad Atif Bilala, Asif Tanveer ${ }^{\mathrm{a} *}$, Muhammad Ather Nadeem ${ }^{\mathrm{b}}$ and Tasawer Abbas ${ }^{\mathrm{c}}$ \\ ${ }^{a}$ Department of Agronomy, University of Agriculture, Faisalabad, Pakistan \\ ${ }^{b}$ Department of Agronomy, College of Agriculture, University of Sargodha, Sargodha, Pakistan \\ 'In-Service Agricultural Training Institute Sargodha, Sargodha, Pakistan
}

(received March 3, 2016; revised November 10, 2017; accepted November 11, 2017)

\begin{abstract}
Weed control is one of the crucial factors to achieve higher yield of good quality forage maize. A field trial was conducted during summer 2013 to investigate the effect of bromoxynil+MCPA+metribuzin (Valent $470 \mathrm{EW}$ pre mixed formulation) application at varied doses to control weeds in forage maize (Zea mays L.) at Agronomy Research Area, University of Agriculture, Faisalabad, Pakistan. Application of bromoxynil+MCPA+metribuzin@470,528.75 and $587.50 \mathrm{~g}$ a.i/ha was made after emergence of weeds and crop. A check with no application and hand hoeing was included for comparison. The experiment was conducted with four replications under randomized complete block design. The data regarding the weed parameters, yield and yield components of maize were recorded. The results revealed that among the herbicide treatments minimum weed density (three weeks after sowing $35.75 \mathrm{~m}^{2}$ and at harvest $12.25 / \mathrm{m}^{2}$ ) and dry biomass $\left(20.80 \mathrm{~g} / \mathrm{m}^{2}\right)$ was observed with the application of bromoxynil+MCPA+metribuzin @ $587.50 \mathrm{~g}$ a.i./ha. Same herbicidal treatment caused significant increase in plant height $(248.75 \mathrm{~cm})$, stem diameter $(1.45 \mathrm{~cm})$, fresh weight $(467.25 \mathrm{~g})$ and forage yield $(31.47 \%)$ of maize. Therefore, use of bromoxynil+MCPA+metribuzin @ $587.50 \mathrm{~g}$ a.i./ha is the best option to manage broad leaved as well as grassy weeds in forage maize to get higher yield of forage .
\end{abstract}

Keywords: post emergence herbicides, weeds, forage yield, maize

\section{Introduction}

Significance of maize as a forage crop in Pakistan requires great importance because regular, sufficient and good quality forage is the basic need of livestock production. Maize is cultivated for grains as well as for fodder purpose throughout the world. It plays a key role in diet of human and animal feed and provides adequate amount of energy and protein (Maiti and Wesche-Ebelge, 1998). Its green forage is palatable, succulent and highly relished by animals. Maize fodder contains $1.56 \%$ protein, $0.30 \%$ fats and $5.20 \%$ fibre (Nazir, 1994) and due to its high productivity and bearing abundant leaf growth, the farmers grow it for green fodder.

In Pakistan, maize as a fodder crop was cultivated on 0.09 million hectares in 2014-15 with a total forage yield of 0.96 million tonnes (GOP, 2015). Among different biotic and abiotic factors which caused reduction in forage yield, uncontrolled weeds have major importance. Worldwide weeds caused on an

*Author for correspondence;

E-mail: drasiftanveeruaf@hotmail.com average $40 \%$ loss in maize which is more than any other yield reducing factor in this crop (Oerke and Dehne, 2004). Weeds losses are higher than other factors including animal pest, fungal and bacterial pathogens and viruses which caused 18,16 and $2 \%$ yield loss, respectively (Oerke, 2005). Most common weeds of forage maize in Pakistan are Trianthema portulacastrum L. (horse purslane), Cyperus rotundus L. (purple nut sedge), Cynodon dactylon L. (bermuda grass), Sorghum halepense L. (johnson grassfvb), Convolvulus arvensis L. (field bindweed), Tribulus terrestris L. (puncture vine) and Achyranthes aspara L. (devil's horsewhip).

To minimize the losses caused by weeds in forage maize, different weed control practices including mechanical, cultural, biological, chemical and integrated weed control can be used. Cultural method can effectively control weeds but that is costly, time consuming and laborious. In Pakistan manual weed control is less effective in maize as maize is grown during hot summer months when temperature is so high that manual weed control is very difficult to imply and this method is also ineffective against $C$. rotundus and $C$. dactylon in maize 
(Sadiq et al., 2008). Large land holding farmers are also facing weed problem due to lack of manual labor and frequent rains in monsoon season at early growth stage of forage maize, as a result cultural or mechanical weed control operations are delayed or left. Exhausted by cultural method, farmers are now trying to adopt other weed control strategies to manage weeds in forage maize. Because weeds not only reduce yield and quality of maize forage but also create problem in forage cutting and animal willpower to eat forage due to toxicity of weeds. In this scenario, chemical weed control is the best option. Because it is easy to use, more effective, time and labor saving method to manage weeds in maize and is suggested by many researchers (Tanveer et al., 2015; Tahir et al., 2009; Juhl, 2004, Skoko et al., 2002).

Many factors which are responsible for the success of chemical weed control include time of weed emergence, time of herbicide spray and growth stage of crop (Vandini et al., 2005). The bromoxynil belongs to the family hydroxybenzonitrile. It is a contact herbicide which inhibits photosynthesis and plant respiration. The MCPA is a member of phenoxy group herbicides. It is a selective herbicide for broad leaved weeds. It disrupts the plant cell growth. Metribuzin is a triazine herbicide. It inhibits the photosynthesis and used as a pre as well as postemergence herbicide to control annual grasses and broad leaved weeds (WSSA, 1989). Many post emergence herbicides are easily available to control broad and narrow leaved weeds in maize, however, their suitability, time, method of application and correct dose to control weeds in forage maize under different agroclimatic environment are needed to determine. Use of higher doses of herbicides should be stressed so that leaching of herbicide to underground water avoided. Due to broad weed control spectrum and reduced application cost, use of herbicides mixtures is preferred over single herbicide application (Jhala et al., 2013). Therefore, this research was conducted to assess the efficacy of bromoxynil+MCPA+metribuzin at varied doses to control weeds in forage maize and its effect on forage yield and yield contributing parameters. Broad weed control spectrum and reduced herbicide dose will help to minimize the environmental safety concerns lie back behind chemical weed control.

\section{Materials and Methods}

A field study to evaluate the growth and yield response of forage maize (Zea mays L.) and its weeds to bromoxynil+MCPA+metribuzin (Valent $470 \mathrm{EW}$ ) application was conducted at Agronomic Research Area, University of Agriculture, Faisalabad, Pakistan during July 2013. The experiment was laid out in randomized complete block design with four replications and a net plot size of $6 \times 1.2 \mathrm{~m}$. The experimental land was ploughed 2-3 times with cultivator followed by planking and then fine seedbed was achieved by using rotavator. Maize synthetic variety Pakafgoyee was sown on $23^{\text {th }}$ of July, 2013 in lines with the help of manual drill. Line spacing was $30 \mathrm{~cm}$. Fertilizer was applied (a) $120 \mathrm{~kg} / \mathrm{N} / \mathrm{ha}$ and $100 \mathrm{~kg} / \mathrm{P} / \mathrm{ha}$. Whole $\mathrm{P}$ was applied at sowing, while $\mathrm{N}$ in two splits, $1 / 2$ at sowing and $1 / 2$ at the time of first irrigation. Application of bromoxynil+ $\mathrm{MCPA}+$ metribuzin at the rate of $470,528.75$ and 587.50 $\mathrm{g} / \mathrm{a} . \mathrm{i} / \mathrm{ha}$ was made after emergence of weeds and crop. A check with no application and hand hoeing was included for comparison. Herbicide was sprayed with a knapsack hand sprayer fitted with flat fan nozzle. Water was calibrated and $300 \mathrm{~L} / \mathrm{ha}$ water was used at 30 psi pressure.

The data regarding the weed parameters, yield and yield components of maize was recorded using standard procedures and was analyzed statistically by applying Fisher' $s$ analysis of variance technique. Treatments' means were compared using the least significant difference test at $\mathrm{P}=0.05$ (Steel et al., 1997).

\section{Results and Discussion}

Total weeds density $\left(/ \mathbf{m}^{2}\right)$. The weeds present in forge maize were Cyperus rotundus L. (purple nutsedge), Trianthema portulacastrum L. (desert horsepurslane), Convolvulus arvensis L. (field bindweed) and Echinochloa colona L. (jungle rice). Data regarding density of all weeds (Table 1) three weeks after sowing and at harvest revealed that all the weed control treatments (hand weeding and herbicides) significantly controlled all the weeds as compared to control plot. The minimum weed density ( 35.75 and $\left.12.25 \mathrm{~m}^{2}\right)$ in maize was recorded where bromoxynil+MCPA+metribuzin@ $987.50 \mathrm{~g}$ a.i./ha was applied and was statistically at par with that of hand weeding. These results are in line with those of Tahir et al. (2009), Mahadi et al. (2007) and Muhammad and Hassan (2003). They stated that weed density was significantly higher in plots where herbicide was not applied and was minimum in chemically treated plots of maize.

Weeds dry biomass $\left(\mathrm{g} / \mathrm{m}^{2}\right)$. Data on dry weed biomass (Table 1) showed that there was a significant difference in the dry weight of all weeds among all weed control 
treatments. Results exhibited that maximum dry biomass of all weeds was observed in control treatment. The minimum dry weight $(20.57 \mathrm{~g})$ of all weeds in maize was observed in hand weeding plot and was statistically at par with that of bromoxynil+MCPA+metribuzin @ $587.50 \mathrm{~g} / \mathrm{a} . \mathrm{i} . / \mathrm{ha}$. Reduction in dry biomass was due to less weed density and suppressed growth of surviving weed plants in herbicide treated plots. These results are supported by Tanveer et al. (2015), Skoko and Zivanovic (2002) and Ammanullah (2001). They reported that the herbicides application reduced the dry weight of weeds significantly in maize.

Plant population $\left(/ \mathbf{m}^{2}\right)$. Number of crop plants in a unit area (plant population) is the major yield contributing factor i.e., more the number of crop plants higher will be the crop yield. The data pertaining to plant population showed that bromoxynil+MCPA+metribuzin at different rates had non-significant effect on the plant population $\left(/ \mathrm{m}^{2}\right)$ at harvest (Table 1$)$. Maximum plant population $\left(22.25 / \mathrm{m}^{2}\right)$ was observed in hand weeding and was statistically similar with those of all other treatments except manual weed control. Decrease in plant population in weed check could be due to more weed competition because higher weed infestation can suppress crop growth and cause death or reduction in survival ability of crop plants. Non-significant effect of herbicide application on maize plant population has been previously reported by Tanveer et al. (2015).

Plant height of maize (cm). Plant height (Table 1) is also an important component of forage yield. The data of plant height of maize recorded at the harvest of crop showed that maximum plant height $(248.75 \mathrm{~cm})$ of maize plant was observed in plots where bromoxynil+ MCPA+metribuzin@587.50g/a.i./ha was applied and was statistically at par with that of hand weeding but the minimum plant height $(237.00 \mathrm{~cm})$ of maize plant was recorded in control treatment.

The difference in plant height of maize might have been due to differential effect of weed competition for light, moisture and nutrients offered by various weed densities in different herbicide treatments. Tahir et al. (2009) reported that herbicides application caused significant increase in plant height of maize over weedy check.

Stem diameter $(\mathbf{c m})$. Data regarding stem diameter showed that all the weed control treatments performed better and significantly affected the stem diameter of maize (Table 1). The data recorded at the harvest of crop showed that minimum stem diameter $(1.38 \mathrm{~cm})$ of maize plant was observed in control treatment but

Table 1. Effect of bromoxynil+MCPA + metribuzin on weed density, weed biomass, yield and yield components of forage maize

\begin{tabular}{|c|c|c|c|c|c|c|c|c|}
\hline \multirow[t]{2}{*}{ Treatments } & \multicolumn{2}{|c|}{ Weed density $\left(/ \mathrm{m}^{2}\right)$} & \multirow{2}{*}{$\begin{array}{l}\text { Dry weight } \\
\text { of weeds } \\
\left(\mathrm{g} / \mathrm{m}^{2}\right)\end{array}$} & \multirow{2}{*}{$\begin{array}{l}\text { Plant } \\
\text { population } \\
\text { of maize } \\
\left(\mathrm{m}^{2}\right)\end{array}$} & \multirow{2}{*}{$\begin{array}{l}\text { Plant } \\
\text { height } \\
\text { of maize } \\
(\mathrm{cm})\end{array}$} & \multirow{2}{*}{$\begin{array}{l}\text { Stem } \\
\text { diameter } \\
\text { of maize } \\
(\mathrm{cm})\end{array}$} & \multirow[b]{2}{*}{$\begin{array}{l}\text { Fresh } \\
\text { weight } \\
\text { per plant } \\
\text { of maize } \\
(\mathrm{g})\end{array}$} & \multirow{2}{*}{$\begin{array}{l}\text { Forage } \\
\text { yield } \\
\text { of maize } \\
(\mathrm{t} / \mathrm{ha})\end{array}$} \\
\hline & 3 WAS & At harvest & & & & & & \\
\hline $\begin{array}{l}\text { Bromoxynil+MCPA+ } \\
\text { metribuzin }\end{array}$ & $66.25 b$ & $33.00 \mathrm{~b}$ & & & & & & $7.40 \mathrm{c}$ \\
\hline @ 470 g/a.i/ha & $(36.45)$ & $(49.03)$ & $31.50 \mathrm{~b}$ & $21.25 \mathrm{a}$ & $243.00 \mathrm{c}$ & $1.43 \mathrm{a}$ & $442.50 \mathrm{c}$ & $(16.10)$ \\
\hline $\begin{array}{l}\text { Bromoxynil+MCPA+ } \\
\text { metribuzin }\end{array}$ & $58.50 \mathrm{c}$ & $26.75 \mathrm{c}$ & & & & & & $77.45 b$ \\
\hline @ 528.75 g/a.i/ha & $(43.88)$ & $(58.68)$ & $31.71 b$ & $20.75 \mathrm{a}$ & $245.50 \mathrm{bc}$ & $1.43 \mathrm{a}$ & $453.50 \mathrm{~b}$ & $(22.50)$ \\
\hline $\begin{array}{l}\text { Bromoxynil+MCPA+ } \\
\text { metribuzin }\end{array}$ & $35.75 \mathrm{~d}$ & $12.25 \mathrm{~d}$ & & & & & & 83.12 \\
\hline @ 587.50 g/a.i/ha & $(65.70)$ & $(81.08)$ & $20.80 \mathrm{c}$ & $22.00 \mathrm{a}$ & $248.75 a$ & $1.45 \mathrm{a}$ & $467.25 \mathrm{a}$ & $(31.47)$ \\
\hline Weedy check & $104.25 \mathrm{a}$ & $64.75 \mathrm{a}$ & $49.65 \mathrm{a}$ & $15.00 \mathrm{~b}$ & $237.00 \mathrm{~d}$ & $1.38 \mathrm{~b}$ & $426.50 \mathrm{~d}$ & $61.22 \mathrm{~d}$ \\
\hline Hand hoeing & $\begin{array}{l}39.75 d \\
(61.87)\end{array}$ & $\begin{array}{l}16.00 \\
(75.28)\end{array}$ & $20.57 \mathrm{c}$ & $22.25 \mathrm{a}$ & $247.50 \mathrm{ab}$ & $1.44 \mathrm{a}$ & $461.50 \mathrm{ab}$ & $\begin{array}{l}79.97 \mathrm{ab} \\
(26.49)\end{array}$ \\
\hline
\end{tabular}

Any two means sharing the same letters did not differ significantly at $5 \%$ level of probability. The data are the means (percent to control). 
the maximum stem diameter $(1.45 \mathrm{~cm})$ was recorded in plots where bromoxynil+MCPA+metribuzin @ $587.50 \mathrm{~g} / \mathrm{a} . \mathrm{i} . /$ ha was applied and was statistically at par with all other treatments except control. Increase in stem diameter belong to less weed crop competition for available resources as herbicide application caused significant reduction in weed density and dry biomass of weeds. These results agree with Tahir et al. (2009) who reported that herbicides application caused increase in stem diameter of maize due to good weed control.

Fresh weight per plant of forage maize (g). It is depicted from the data that bromoxynil+MCPA+ metribuzin at different rates significantly affected the fresh weight per plant of maize (Table 1). The data recorded at the harvest of crop showed that maximum fresh weight per plant $(467.25 \mathrm{~g}$ ) of maize was observed in plots where bromoxynil+MCPA+metribuzin @ $587.50 \mathrm{~g} /$ a.i./ha was applied and was statistically at par with that of hand weeding but the minimum fresh weight per plant $(426.50 \mathrm{~g})$ was recorded in control treatment. More fresh weight of maize in herbicide treated plots was in accordance with more plant height and stem diameter of maize. Role of attributing factors on maize biomass have been reported previously by Hassan et al. (2010) and Tahir et al. (2009).

Forage yield of maize (t/ha). Data regarding the forage yield (Table 1) showed that bromoxynil+MCPA+ metribuzin at different rates and hand hoeing significantly affected the forage yield of maize. It is evident from the data that the maximum forage yield of maize $(83.12 \mathrm{t} / \mathrm{ha}$ ) which was $31.47 \%$ more than weedy check was obtained where bromoxynil+MCPA+metribuzin (a) $587.50 \mathrm{~g} / \mathrm{a} . \mathrm{i} . / \mathrm{ha}$ was applied and was statistically similar with that of hand weeding having forage yield of $79.97 \mathrm{t} / \mathrm{ha}$. The minimum forage yield of maize $(61.22 \mathrm{t} / \mathrm{ha})$ was observed in control treatment. Variation in forage yield of maize might have been due to differential response of maize plants to weed control treatments. Increased forage yield was achieved in plots where weeds were controlled. It was the result of improved growth and development in terms of plant population, plant height, stem diameter and fresh weight per plant of maize. These outcomes are reinforced by the research work of Hassan et al. (2010); Haider et al. (2009) and Muhammad and Hassan (2003) who mentioned the role of yield contributing factors and enhanced yield on account of good weed control with application of herbicides.

\section{Conclusion}

Based on present results it can be concluded that application of bromoxynil+MCPA+metribuzin @ 587.50 g/a.i./ha as post emergence herbicide mixture gave up to $81.08 \%$ weed control and $31.47 \%$ more forage than untreated maize.

Conflict of Interest. The authors declare no conflict of interest.

\section{References}

Ammanullah, S. 2001. The effect of different herbicides on weed population and yield of maize (Zea mays L.). Pakistan Journal of Agricultural Sciences, 38: 75-77.

GOP, 2015. Pakistan Bureau of Statistics 2014-15. Ministry of Finance, Govt. of Pakistan, 17 pp.

Hassan, G., Tanveer, S., Khan, N., Munir, M. 2010. Integrating cultivars with reduced herbicides rates for weed management in maize. Pakistan Journal of Botany, 42: 1923-1929.

Hoverstad, T.R., Gunsolus, J.L., Johson, G.A., King, R.P. 2004. Risk efficiency criteria for evaluating economics of herbicides based weed management system in corn. Weed Technology, 18: 687697.

Jhala, A.J., Ramirez, A.H., Knezevic, S.Z., VanDamme, P., Singh, M. 2013. Herbicide tank mixtures for broad-spectrum weed control in Florida citrus. Weed Technology, 27: 129-137.

Juhl, O. 2004. Maister the most broad spectrum herbicide for maize in Denmark. Denske Plantekongres Plantebeskyttelse, Murkbrug. No. 99, 7-14. (CAB Absts., 2004).

Mahadi, M.A., Dadari, S.A., Muhammad, M., Babaj, B.A., Mani, H. 2007. Effect of rice based herbicides on yield and yield components of maize. Crop Protection, 26: 601-605.

Maiti, R.K., Wesch-Ebeling, P. 1998. Maize Science, 323 pp., Oxford and IBH Publishing Co.Pvt.Ltd. New Delhi, Culcutta, India.

Muhammad, K., Hassan, W. 2003. Effect of S Metolachlor (Dual Gold 960EC) on weed control and yield in different crops. AGRIS, 19: 333-339.

Nazir, S. 1994. Fodder Crops. In: Crop Production, pp. 391-417. National Book Foundation, Islamabad, Pakistan.

Oerke, E.C. 2006. Crop losses to pest. Journal of Agricultural Sciences, 144: 31-43. 
Oerke, E.C., Dehne, H.W. 2004. Safeguarding production-losses in major crops and the role of crop production. Crop Protection, 23: 275-285.

Sadiq, M., Ullah, W., Khan, M.A., Arifullah, S. 2008. Evaluation of integrated weed management practices for maize. Pakistan Journal of Weed Science Research, 14: 19-32.

Skoko, H., Zivanovic, D. 2002. Weed control by herbicide in maize under agro-ecological conditions of Semberia. Weed Science Society of Bosnia and Herzegovina, 3: 99-105.

Steel, R.G.D., Torrie, J.H., Dickey, D.A. 1997. Principles and Procedures of Statistics. A Biometrical Approach. pp. 172-177, $2^{\text {nd }}$ edition, McGraw Hill Book Co. Inc., Singapore.
Tahir, M., Javed, M.R., Tanveer, A., Nadeem, M.A., Wasaya, A., Bukhari, S.A.H., Rehman, J. 2009. Effect of different herbicides on weeds, growth and yield of spring planted maize (Zea mays L.). Pakistan Journal of Life Social Sciences, 7: 168-174.

Tanveer, A., Ahmad, S., Abbas, R.N., Zafar, M., Ali H.H., Buriro, M. 2015. Field validation of ammonium sulphate as an activator adjuvant on bromoxynil + MCPA + metribuzin efficacy against maize weeds. Pakistan Journal of Weed Science Research, 20: 283-293.

WSSA, 1989. Herbicides Handbook of the Weed Science Society of America, $6^{\text {th }}$ edition, WSSA, Champaign, IL, USA. 